\title{
Identifying the customer satisfaction factors in furniture market
}

\section{Majid Azizi *, Seyed Alireza Dehghan **, Mohsen Ziaie ***, Nematollah Mohebi}

* College of Agriculture and Natural Resources, University of Tehran,

16th Azar St., Enghelab Sq., Tehran, Iran

Professor, Faculty of Natural Resources

** College of Agriculture and Natural Resources, University of Tehran,

16th Azar St., Enghelab Sq., Tehran, Iran

MS Graduate Student, Faculty of Natural Resources

*** Universiti Putra Malaysia, Malaysia,

Jalan Upm, 43400 Serdang, Selangor, Malaysia

**** College of Agriculture and Natural Resources, University of Tehran,

16th Azar St., Enghelab Sq., Tehran, Iran

PhD, Faculty of Natural Resources

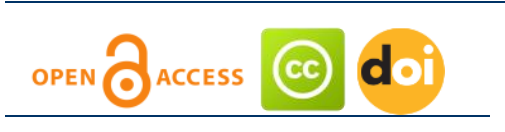

Article history:

Received: April, 2017

1st Revision: April, 2017

Accepted: April, 2017

\section{JEL classification: \\ D4}

L11

Q13

\section{DOI:}

10.14254/jems.2017.2-1.1

\begin{abstract}
:
Purpose - the purpose of this research is to identify the influential factors on customer satisfaction in the Iranian furniture market in order to get acquainted with the fundamental items for planning future sales programs with the purposes of extolling competitive advantages.
\end{abstract}

Design/methodology/approach - A commixture of 6 items and 31 factors were educed from interviewing with 20 experts in furniture designing and manufacturing industry. The collected data from customer need indexes in previous research were also used.

Findings - results showed that such factors as economic factors weighting 0.32 , product specifications weighting 0.21 and credibility weighting 0.19 were the most important indexes and price weighting 0.195, fame weighting 0.131, quality, durability and resistance weighting 0.116, paying conditions weighting 0.095, designing and decorating in virtual softwares before ordering weighting 0.074 , updatedness weighting 0.064 and interaction approach with the weight of 0.42 were the most considerable influential sub-indexes on the satisfaction of the Iranian furniture market customers.

Research limitations/implications - by the enhancement of competition throughout the world markets and the inevitable presence of Iran in it, the market activists' concentration should shift towards paying comprehensive attention to desires and needs of furniture market 
customers.

Practical implications - some important issues on planning suitable manufacturing and marketing programs in furniture market are introduce so that the activists be aware of considering the growing knowledge and awareness of end-users which increases the pressure on the manufacturer side. There are also some solutions in terms of internal and external organizational factors with regard to the complex nature of competitive environment in furniture market.

Originality/value - the paper provides an examination of effective factors on customer satisfaction with a focus on past experiments and the perspectives of furniture market experts.

Keywords: customer satisfaction, furniture industry, marketing furniture.

\section{Introduction}

The intense competition and the resulting pressure that comes with it, have influenced the pricing processes and hence caused the manufacturers to try to recognize the potential capacities of the markets and potential customers while struggling to enhance their share of present markets, as well. In such markets, survival is the effect of attracting and keeping customers. Generally speaking customer orientation is one of the most important and strategic notions in terms of keeping and developing markets. This is to say that more share in the market is a function of keeping old customers while attracting new ones and by the advancement of economic competitions, gaining maximum profit is only conceivable by paying due attention to the customers. The testaments to this are the researches of Boston Consultant Group indicating that the return on investments of old customers are 9 times greater than the investment return of new customers and also the expenses of attracting a new customer is 10 to 15 times more than keeping and old one (Kotler, Armstrong, Saunders, \& Wong, 2001). Moreover when losing customers, especially the key ones, this loss has a great negative impact on the outcomes of our company. Furthermore in another research it was mentioned that attracting a new customer has 6 times more expenses than keeping a current one, in other words usually keeping a customer is much cheaper than finding one. But it must be kept in mind that both these processes are difficult and costly. A loyal and satisfied customer might bring in great amounts of money for us for several years, especially if he is encouraged by the companies incentive strategies. Therefore having interaction with current customers is much more inexpensive than finding new ones (Hayes \& Dredge, 1998).

After the industrial revolution the focus of marketing strategic policies was on expanding the range of customers and attracting new ones but nowadays the main concentration is on keeping, promoting loyalty and expanding the brand trust of the customers (Light, 2003). The main reason for this shift is enhanced knowledge and awareness of companies about customers' loyalty and satisfaction. Those companies that have greater share on loyal customers side, have more competitive advantages in rivalry with other companies, some of these advantages are as follows: high rate of re-buying from longtime customers, lowering the advertisement expenses (as a result of word of mouth advertising) and low propensity for changing suppliers of goods and services (ibid).

Research findings show that $96 \%$ of costumers never complain about unpleasant behavior of staffs and adverse quality of goods and services, instead $90 \%$ of them never go back to buy anything from the same company. At the same time, $30 \%$ of these unsatisfied customers transmit their emotion to more than 20 people and the remaining dissatisfied customers transmit it to at least 9 other persons (Hayes \& Dredge, 1998). These findings also indicate that the expenses needed to attract a new customer are 10 to 15 times more than the amount needed to keep and old one. Essentially keeping a customer is much cheaper than searching for a new one (ibid).

Accordingly the results of measuring the quality and quantities relating to customer satisfaction is a befitting approach not only to find successful organizations but also to introduce important strategic decision making indexes for evaluation and improvement of a company's performance. This approach has proven to deliver its advantages in such grand companies as Toyota and Motorola. Existence of a persistent relation between customers and organizations is dependent to the appropriate performance of the organization's customer relationship 
management, a system that must have comprehensive knowledge and understanding about trust making, sense of commitment and loyalty in customers. Till now experts have recognized numerous indexes as key words of customer relations but most of them believe that this relation should be interwoven with such concepts as trust, feelings and commitment (Sun \& Min, 2009).

In the last three decades, the furniture industry has grown rapidly and as an industry which relies on simple technologies it has become one of the most important international ones. As Kaplinsky et al. (2003) stated this industry has had a 36\% growth rate between 1998-2000, which was more than the total growth rate of business, garment and footwear industries which were respectively: $26.5 \%, 32 \%$ and $1 \%$. This research also confirmed that furniture industry had the greatest share in simple technologies industries (Kaplinsky, Memedovic, Morris, \& Readman, 2003). Such characteristics like needing simple technology and having a vast market have caused this domain to become one of the most crowded ones competition wise (Ziaie, Shukri, Ratnasingam, Awang Noor, \& Rosli Saleh, 2012). By and large these intense competitions inevitably make companies try to preserve and develop their markets by attracting and keeping their customers, a process that its focus should be on principles of relationship management and customer satisfaction. Such procedures highlight the necessity of research in the field of customer satisfaction in furniture industries to make company's survival and development feasible. In Iran also, where foreign companies have tried to consolidate their place in the market in recent decades, the enhancement of this industry has been vigorously visible, especially in the last five years. In this market as well the importance of customer satisfaction issues have been unveiled (Ziaie, 2010). In order to achieve the goals of this research, we'll introduce the indexes of customer satisfaction in Iranian consumers and then rank the key factors accordingly.

\section{Customer Satisfaction in previous research}

In 1977, Oliver first explained the notions of customer satisfaction and its measuring instruments, he defined satisfaction as desirability and pleasantliness of past procurement experiments. Also Kano in 1985 did some research on this matter and introduce 3 categories of customer needs, namely basic needs, operational needs and motivational needs (Siskos \& Grigoroudis, 2004). Afterwards Fornell brought forward in 1989 the Swedish customer satisfaction index after which he introduced the American customer satisfaction index in a five year period, in 1994 (Fornell, 1996). At the emergence of these approaches, Ivara (1997) exploited some of the common statistical models like multiple linear regression and cluster analysis to measure the amount of customer satisfaction (Varva, 1997). Furthermore Siskos and Grigoroudis (1998) expanded the domain and depth of analyzing customer satisfaction and introduced a multi-criteria model for measuring this phenomenon. They further expanded their model in 2000 and 2002 (Siskos \& Grigoroudis, 2002). In this model total and partial customer satisfaction is measured according to their own judgments. In contrast with previous model, Siskos and Grigoroudis model prepared the necessary criteria for involving the customers' judgment mechanism more vigorously in the measuring process. Jamal and Naser (2002) defined customer satisfaction as a feeling or attitude of a customer towards a product or service after using it (Jamal \& Naser, 2002).

Moreover Roy (1977) suggested that fuzzy characteristics should be employed in defining and explaining descriptive expressions and also succeeded in ranking the necessities of designing a product by presenting the fuzzy priority method. Siskos et al. (1977) also presented a special priority relation for weighting and prioritizing indexes as well (Siskos \& Grigoroudis, 2004). Wasob (1989), Busert (1990) and Fraiser (1990) explained their research findings as follows: customer needs can be expressed in form of quantitative (actual) or qualitative (descriptive) variables but for measuring these needs, one should gauge the qualitative words as quantitative variables as well (Chen \& Hwang, 1992). $Z u$ (1999) introduced the index weighting/ranking technique on a fuzzy logic basis in which the "if...then" law was exploited (Siskos \& Grigoroudis, 2004). Moreover Jeong \& Lee (2010) in their research about analyzing the influential factors on customer satisfaction in the online furniture purchasing process recognized such items as: product variety, quality of service, responsiveness, interaction and durability as the key influential factors. They also found out that customer satisfaction is the influential factor on customers' loyalty in online procurement (Jeong \& Lee, 2010). Eventually Purnima \& Preety (2011) in their research on customer expectations from mobile phone CRM in the banking field stated that perception of consumed value is the most important factor for presenting CRM services in mobile phone domain. From those other influential factors are ease of use, context, innovation compatibility, expenses, risk and personalization. Moreover having a negative attitude towards technology was recognized as an item which needs further research (Purnima \& Preety, 2011). 


\section{Customer Categorization}

Based on several researches, customers can be categorized in three classes according to their loyalty level towards a brand or company (Bull, 2003): high level customers: including loyal and more profitable customers. Customer relationship management should consider providing the best services for this group and prevent them from switching to other companies; middle level customers: this class includes $40 \%$ to $50 \%$ of the total customers that have potential capacity to grow their loyalty rate. Since this group is the largest source of potential growth for the company's future, CRM should aim for this class; low level customers: these are the customers who have the least profitability for the company, hence expenses and efforts in alignment to aiming on them spoils the efforts done in the two other groups (Bull, 2003).

\section{Customer Relationship Management}

Reed and Hall (1977) declared that customer satisfaction is communication oriented, that is there exist some links between customers and products (or services), customers and manufacturers and finally manufacturers and their products (Reed \& Nicholusp, 1977). Also Light (2003) introduce three perspectives on the CRM notion: 1.strict compliance between products and customers' needs in order to guarantee the sales; 2.coherent monitoring of customers to have permanent relation with them by the means of communication centers; and 3.focusing on customers' databases using CRM and data support systems (Light, 2003).

In other words CRM is the strategy of a business with the focus on customer approach that its aim is increasing customer satisfaction and loyalty by the means of providing more and even customized services. During the last 20 years, the emergence of internet and large stores besides the development of suburbs, have caused customer relations to get more complicated. In this regard most of the organizational efforts have been concentrated on gathering sporadic data from thousands of sources and identifying, attracting and keeping new customers (Seeman, Elain, \& Margaret, 2006). With the expansion of this approach CRM has become one of the main strategies of businesses that results in increased income and company's profit through extolling customer satisfaction and loyalty. In this regard the CRM objective is to maximize the company's life cycle and customer value in it (K.Blery \& G.Michalakopoulos, 2006). Nowadays CRM relies on gathering more information from customers and markets through which it can improve individual interactions. It must be kept in mind that CRM includes two fields namely practical and analytic. The practical field covers data collection and the analytic field includes data analysis. So the CRM is a complex of business strategies (with the focus on customers) and software that are aiming at increasing processes relating to customer relations and its management. Therefore, although CRM is often a complicated and difficult task, but the profit that organizations gain from it, is much more considerable (Seeman, Elain, \& Margaret, 2006).

\section{Customer Satisfaction Notion}

Customer satisfaction is explained as the feeling or attitude of a customer towards a product after using it, this satisfaction is a result of a comprehensive durable marketing system (Jamal \& Naser, 2002). There have been several explanations in terms of customer satisfaction on the marketing theorists' side. In one of the most agreed upon theories, Kotler defined it as the degree to which a company's actual performance meets customers' expectations. In Kotler's perspective, if the company's performance meets customers' expectations, he will feel satisfied and otherwise discontent (Kotler, Armstrong, Saunders, \& Wong, 2001).

\section{Measuring Customer Satisfaction}

Measuring is a symbolic procedure used for indicating the aspects and realities of researcher's analytic world. The objective of measurement is transmitting characteristics and properties of experimental events so that the researchers become able in analyzing them. Furthermore for controlling a variable or event or even a process, there must exist some information about them which can be defined by measuring variables. Quesada and Gazo (2007) stated in their research about the method of determining key processes of internal businesses on the basis of critical success factors, that vision is the most important factor in an organization's success which should be taken into consideration before studying critical success factors. They also introduced customer services, production management, and the quality and price of products as the most important critical success factors (Quesada \& Gazo, 2007). Measuring customer satisfaction 
enables the organization to define its strategies, evaluate its performance and keep its customers for a long period of time.

\section{Customer Needs}

According to Kano's Model, customer needs are considered as the occurrence of a certain feeling in customers in case of existence or absence of a specific quality in a product; these needs are categorized in three classes: $a$. fundamental needs: the need that in its absence customers won't accept the product. These are the qualities that a product has to have according to its definition although its existence will not cause such feelings as complacency and joy in customers. In furniture industry stability, appropriate ergonomic dimensions and product updatedness are of these kind; $b$. operational needs: these are the needs that not satisfying them will causes less satisfaction for customers and their satisfaction enhance the customer satisfaction level. It must be kept in mind that the absence of operational needs can still cause customers to cancel their purchase. In other words being alert to these kinds of needs may result in customer preservation while ignoring them may lead to losing them. An example of this kind of need in furniture industry is exploiting modern fitiings in products; c. attractive needs: the need that its satisfaction results in feelings of complacency and joy in customers while its absence in no way causes discontent in them. This kind of need is categorized in innovation and creativity field of production and is one of the key success factors in competitive markets. Using hidden steel plates and anti-theft doors or furniture's multifucntionality are some example for this kind of needs.

\section{Research Objectives}

Considering the principles and literature review of customer satisfaction field, the aim of this research is identifying, weighting and prioritizing customer satisfaction factors in furniture industry of Iran.

\section{Research Questions}

In this paper we are trying to observe that: $a$. what the influential factors on customer satisfaction of furniture markets in Iran are?; b. what the weight of each one of these influencing factors are?; and c. what quality does the ranking of these factors enjoy?

\section{Design/methodology/approach}

This research in its nature is an applied one and with regard to the data collection approach is of exploratory and descriptive kind, moreover cross-sectional method has been used to put it in operation. Finally the research variables have been explained and evaluated in the target population.

\section{Data collection and Variable definition}

In order to clarify customer needs, three methods have been exploited for derivation and collection of data: a. library studies, $b$. the information gathered from interviewing 20 experts in the field of furniture design and production, active academicians in furniture markets and those that had great experiences in furniture sales and marketing, c. exploitation of statistical information from previous research.

For starters, a list of expectations and needs of Iranian customers in furniture market was developed using archived information and literature review. Then 20 experts in the field were interviewed, the combination of which was as follows: three manufacturers, eight sales experts, five university professors, two professors who were also manufacturers and two designers who were at the same time sales experts. The interviewees were asked to provide their opinions about the accuracy of the stated needs and addition of possibly unregarded items. The interviewees were selected according to their education, expertise and experience levels. Each interview took about one and a half hour to complete. The respondents were totally free to express their ideas about the issue and all of their statements were recorded. At last 31 sub-indexes of 6 main factors were identified as influential factors on customer satisfaction in Iranian furniture markets which are presented in a cluster form. 


\section{Theoretical Model}

After identifying the influential factors, the decision making tree (hierarchy) with regard to these indexes was drawn upon (figure 1). After introducing the theoretical model, paired comparison questionnaire for indexes and sub-indexes was prepared. In the next step this questionnaires were distributed among thirty experts and manufacturers in furniture industry. From the responded questionnaires those that had less than 0.1 inconsistency rates (inconsistency rates near 0 ) and the ones with that were devoid of prejudicing were selected. Then the collected data from individual judgments were transformed for collective judgment (for each paired comparison) using their geometric mean.

\section{Analytic Hierarchy Process (AHP) for determining the Degree of Importance (weighted value) of each index}

AHP is a hierarchical analysis process for decision making via which multi criteria decisions can be made. In this method, first the structure is prepared, then suitable criteria for decision making are compared to each other and then their weighted value is determined. The numbers that are used for binary comparison are ranging from 1/9 to 9 which is a standard method of measuring. AHP application is based on three principles: a. structure creation and its decoration according to the subject; $b$. superiority establishment through binary comparison; and c. rational consistency establishment through measuring. The mechanism of this method is that the hierarchies for influential criterions and their subsets which impact the production manager's decision makings are designed in furniture production sites, Then a questionnaire is prepared for binary comparison between criterions and their subsets and thereupon weighted value of each criterion and its subsets are calculated. The geometric means are computed using formula 1 (Ziaie, 2010):

$$
\left(a_{12}\right)=\left[\left(a_{12}\right) 1 \times\left(a_{12}\right) 2 \times \ldots \times\left(a_{12}\right) n\right] \times 1 / n
$$

Figure 1: Decision making cluster (hierarchy) the customer satisfaction indexes beside their subsets in furniture market

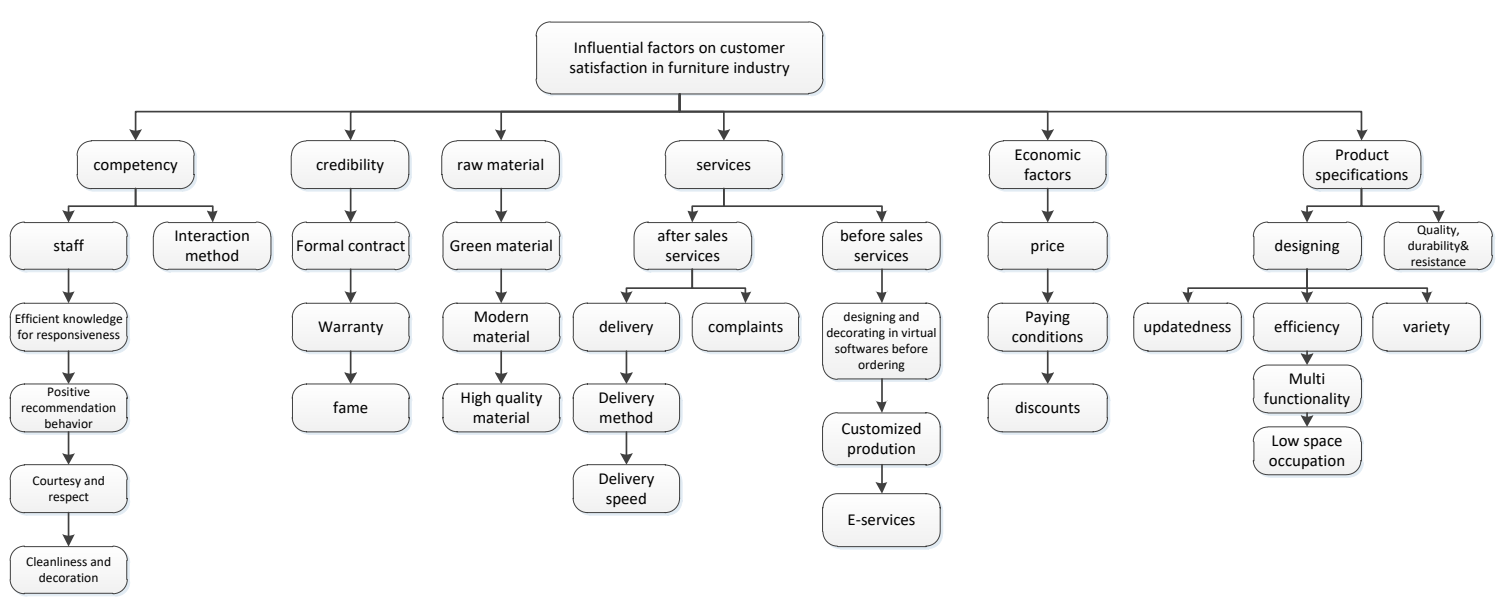

Source: research findings

After the geometric means for each matrix cell have been calculated, the outcomes are normalized and the standard weighted value and its subsets are achieved through combining the weight of low ranked items with the weighted rate of high ranked items. According to Saaty, the AHP method inventor, in order to make judgments consistent the inconsistency rate of matrixes must be equal or less than 0.1 (Chen \& Hwang, 1992). If in some matrixes, the inconsistency rate were less than 0.1 , the experts have to reconsider his/her judgment to make matrixes consistent and then calculate the geometric mean from comparing matrix cells to comparative matrixes. The weights of indexes and their subsets are determined using the related paired comparison matrixes by Expert Choice® software. 


\section{Results}

\section{Weighted values and Indexes Ranking}

The weighted values of influential factors on customer satisfaction are illustrated in figure 2 . This figure shows that the most influential factors are respectively: economic factors weighting 0.33 , product specifications weighting 0.212 , credibility weighting 0.189 , services weighting 0.145 , raw material weighting 0.068 and competency weighting 0.056 . with regard to this results, the economic factors, product specifications and credibility were the ones that ranked higher than the others.

Figure2: The weighted value of influential factors on customer satisfaction in the Iranian furniture market

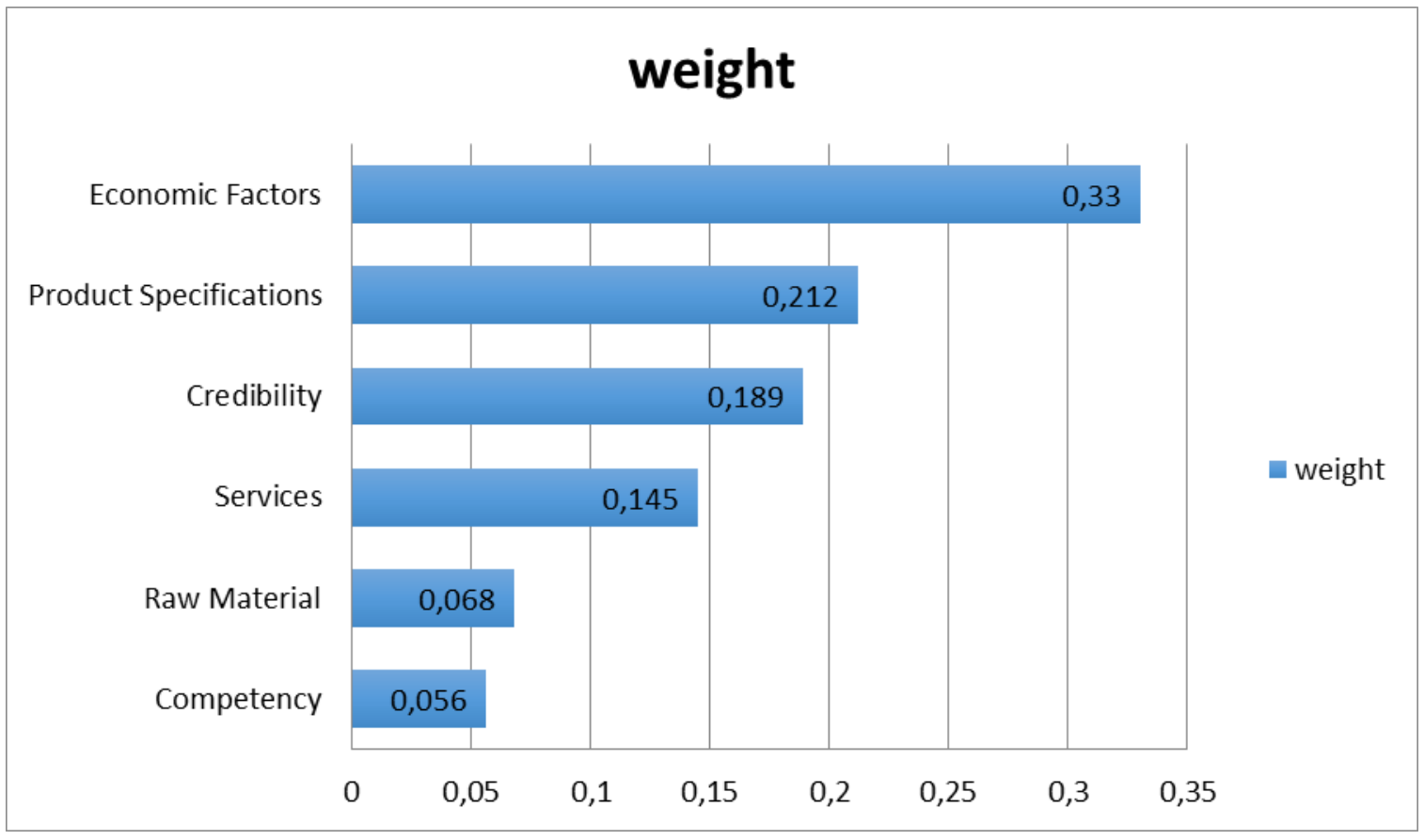

Source: research findings

\section{Discussion and Conclusion}

\section{Economic Factors Index}

Research findings show that with regard to the decentralized and competitive structure of furniture market, economic factors (i.e. financial-cost) are the key principles in decision making. We have to keep in mind that vast presence of SMEs in furniture industry besides their low liquidity, puts such factors as looking for the cheapest and the most available financial sources, paying due attention to the costs of raw materials, workforce and overheads in focus of their consideration (Ratnasingam, 1999). Therefore the existence of economic factors item ahead of the most influential factors list is totally rational and consistent with the normal structure of this industry. It's worthy to mention that the two sub-indexes of price weighting 0.195 and paying conditions weighting 0.095 respectively have the most important role in increasing the weight of economic factors ranking.

\section{Product Specifications Index}

In product specifications index, with the weight of 0.212 , there exist such sub-factors as quality, durability and resistance weighting 0.116 and updatedness weighing 0.065 as the most important items in product specifications that makes paying more attention to customers' needs inevitable. So consistency and appropriateness are at the same time the key factors of satisfying customers and also the biggest challenge in face of developing companies (Ziaie, 2009). Accordingly 
the focus of most products is on the needs, expectations and tastes of customers in target markets in order to preserve and enhance the company's share (Philips \& Byung-Rae, 1998). The product specifications position as the second influential item that has impact on customer satisfaction is also rational and consistent with the structure and competitive nature of this market and also confirms previous research findings.

\section{Credibility Index}

These items is defined as credit or documents that provide definite commitment for paying the prices (Dröge, Vickery, \& Markland, 1994; Vickery, Dröge, \& Marklan, 1997). At the sub-index of credibility with the weight of 0.189 , there exist such factors as fame weighting 0.131 and formal contract weighting 0.041 which amplify this index.

\section{Identifying and Ranking the Sub-Indexes}

The results of calculating the weighted value of sub-indexes is illustrated in figure 3 . According to the research results for calculation of weighted values and ranking 31 sub-indexes using the importance-satisfaction matrix, the following factors were identifies as the most influential items on customer satisfaction respectively: price weighting 0.195, fame weighting 0.131, quality, durability and resistance weighting 0.116 , paying conditions weighting 0.95 , designing and decorating in virtual software's before ordering weighting 0.74 , updatedness weighting 0.64 and interaction method weighting 0.42 .

\section{Further Explanations}

\section{Price weighting 0.195}

Price in its nature is evaluation, measurement, size and criteria. Price in market is defined as the transactional value of each product and service that is expressed in terms of monetary unit. In its economic sense, price is the amount required for presenting a product or service. Economists proposed several theories regarding the price issue, and one of the oldest ones is "defining the product's price according to the applied value" theory in which the applied value is expressed as the amount of usefulness and satisfaction that is achieved by using the product for its consumers (Tafazoli, 1977). On the other hand considering the competitive environment of furniture market in the last two decades, the lower price strategy has been the main strategic focus for furniture manufacturers especially in developing countries (Ziaie, Shukri, Ratnasingam, Awang Noor, \& Rosli Saleh, 2012). In fact the effort for producing a commodity with the same quality as those of the competitors but with lower price is one of trying to get aligned with customers' needs which can be used as a lever in competing with rivals. Therefore price position as the most influential sub-index on the customer satisfaction, is totally rational regarding previous research and experiments.

\section{Fame weighting 0.131}

The specific value of a brand is one of the fundamental issues in today's organizations which influence the marketing strategies broadly. A brand is the embodiment of company's fame (Mooteni, 2011). According to Owing et al. (2010) nowadays companies have considered the importance of organization's fame besides such factors as location. Now the fame of a company is more than just the intellectual image of the company's identity (Yongju \& Yongsung, 2010). From the perspective of many researchers, a company's fame can be accounted as a source of strategic value. As Fomborn (1995) and Bromely (2002) stated, fame is: the accumulation of customers' evaluations about the behavior and previous achievements of a company in presenting value and benefit to its multiple beneficiaries (ibid). in other words an organization's fame is the result of customers perceptions of their experiences and direct and indirect information which is drawn upon company's previous performance (Jamal \& Naser, 2002). The advantages of having good fame includes lower operational expenses, high rate of customer returns and consequently high sales rates and the possibility of raising prices (Quesada \& Gazo, 2007). In fact the fame of the companies which is displayed in the form of brands, is one of the most important solutions for customers to select their product according to their desire, taste and satisfaction. So the position of fame as the second influential sub-factor on customer satisfaction is consistent with the proven processes of decision making and purchase cycle of Iranian furniture market customers. 
Figure 3: The weighted value of influential sub-indexes on customer satisfaction in the Iranian furniture market

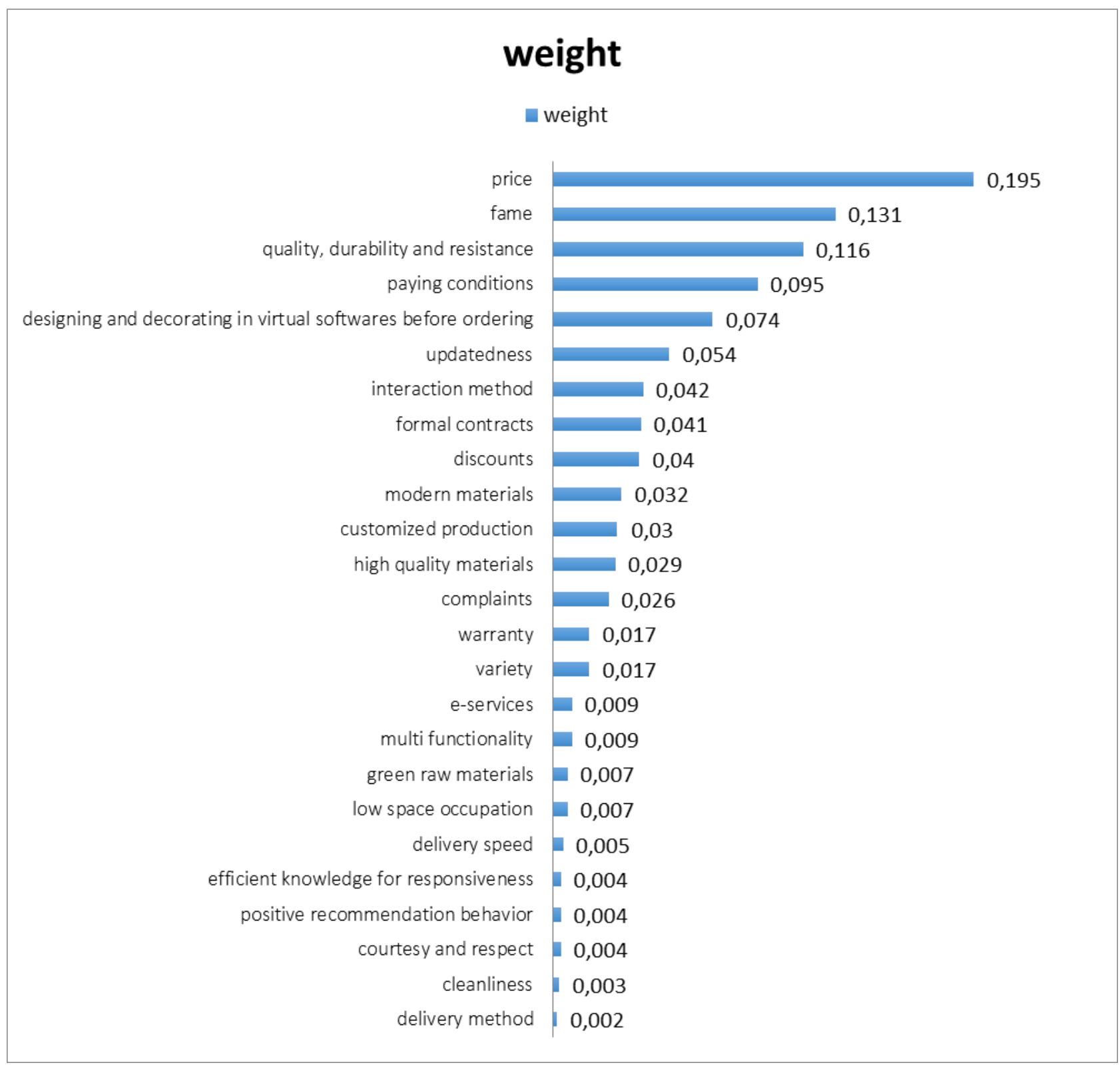

Source: research findings

\section{Quality, Durability and Resistance weighting 0.116}

Being satisfied about the product specifications is the result of a subjective judgment about it, which occurs from evaluating the performance, efficiency and product specifications by customers. This index has a great impact on defining and knowing the product and decision making process of the customers. Quality, durability and resistance are of the most influential factors on product sales and the role of the quality-price combination in pursuing buyers to purchase the product is of great importance. According to Schlesniger's "cycle of desired services", increasing the satisfaction level will result in heightening the threshold of customers in paying more amounts for the products (Hoseini, 2003). In other words although lower prices is an important factor in selecting a product with the same quality, but the quality, durability and resistance factor can be a reason for preferring an expensive product over cheaper ones. In recent years this has caused some furniture market manufacturers who had chosen low price strategy before to shift into differentiation strategies in order to gain higher profit margins and preserve their market share to get away from competitive market pressures by focusing on the quality of their own product. Gaining such capitals as "brand value", "loyal customers and price" and "durable competitive 
advantages" are the results of such strategies (Ziaie, Mohamed, Ratnasingam, Noor, \& Saleh, 2011). So this item's ranking in the third place among influential sub-factors on customer satisfaction is totally in alignment with demographics of consumers throughout the world.

\section{Paying Conditions weighting 0.95}

As Prelec and Simester stated in1998 during their first series of researches on the impact of modern paying methods on customer's satisfaction, credit card paying method has a positive impact on customer's will for buying. Their results also indicated that the benefit of those customers who pay their amount via credit cards was much higher than the other methods of paying for salesmen (Drazen \& Simester, 1998). Also in this regard the finding of Soman et al. (2007) showed that those customers who paid by the use of credit cards, had more flexibility and propensity than cash payers. Their research also illustrated that installment payment had a positive impact on purchasing propensity, especially in case of capital goods (Dilip, Kinzil, \& Walker, 2007). While the position of paying conditions is consistent with previous research, it must be kept in mind that the growing of middle class in the last two decades has resulted in vast consuming culture changes of many Iranians and has made some of the luxury furniture items as necessary ones in the Iranian houses (Ziaie, 2010). Facilitating the payment of furniture will cause more satisfaction for its consumers (ibid).

\section{Designing and decoration in virtual software before ordering weighting 0.74}

The pressures of competition on one hand and the facilities brought about by them on the other hand have made virtualization a lever for customers to reach their ultimate designs of furniture (Beier, 1998). previous researches have proven that consumer behavior in selecting and purchasing furniture has very complexities that are resulted from different factors, of which the impact of their lifestyle is the most (Applied Research \& Consulting LLC, 1999). In this regard Oh et al. (2004) after working on the capabilities that come from objective virtualizations of products for customers, introduced this item as one of the most important levers that can bring customer satisfaction around for American furniture manufacturers which can help them in defeating foreign rivals (Oh, Yoon, \& Hawley, 2004). Accordingly this item's $5^{\text {th }}$ place in the Iranian market is rational and vindicable.

\section{Updatedness weighting 0.63}

Szymanowski and Olkowicz (2010) performed a research in Poland in which they came to the conclusion that the rate of updating products have a great impact on the taste of its consumers (Szymanowski \& Olkowicz, 2010). This was to confirm the previous researches which insisted on the strategic importance of innovation and updated responsiveness to the consumers' needs and desires in enhancing the company's capabilities to preserve its customers (Ziaie, 2010). The ranking of this items is also rational with regard to several aspects of competition in the Iranian furniture market.

\section{Interaction Method weighting 0.42}

In his research on identifying the mutual impact of companies and customers during the purchasing process, Thompson (1998) stated that the most important outcome of a company's interaction with its costumers is "learning". An outcome that with regard to its details and provisions, some important secrets about the customer satisfaction and preservation can be revealed (Thompson, 1998). Vassilios et al. (2001) did a research on the role of customer interaction in development of SMEs and came to the conclusion that those SMEs which focus on customer interaction issue and put his desirability at the center of their attention and the basis of their strategic planning, will be more successful in competing with their rivals (Valsamakis \& Sprague, 2001). Therefore the importance of interacting with customers cannot be ignored because of its important role in company's development and there upon this factors $7^{\text {th }}$ ranking is totally rational considering previous researches regarding company-customer interactions.

\section{Conclusions}

The findings indicate that the key influential factors in the Iranian furniture markets are very much like the factors in furniture markets elsewhere the world (Yongju \& Yongsung, 2010). This 
suggests the Iranian market is not isolated from the competitive furniture market of the world and the experts in this field have a good perception of this fact. There is no doubt that by the enhancement of competition throughout the world markets and the inevitable presence of Iran in it, the concentrations will shift towards paying comprehensive attention to desires and needs of furniture market customers which were introduced in a group of seven sub-indexes. Furthermore two of these seven influential items have external sources while the other five have internal origins. Price as the first and most influential factor on customer satisfaction and paying conditions as the $4^{\text {th }}$ one are the two externally sourced items which are under direct influence of decisions and policies made by governments in economic context. The strictly governmental and oil orientated structure of the Iranian government is a matter that amplifies the government's role in this issue. Monetary and banking policies, customs policies and the government's approach towards national production are some of the external factors that directly influence the production costs (i.e. the price of raw materials, wage and overhead costs) and the competitiveness of furniture production units in Iran, a process that eventually determine the customers' selection quality for choosing between Iranian and foreign products.

It's worth mentioning that at the present time, the dominant conditions have caused very high expenses costs and loss of competitiveness on the side of Iranian products. Regarding the two external items, we have to keep in mind that the importance and impact of internal factors such as "fame", "quality", "virtual designing and decorating", "updatedness" and "interaction" should not be ignored because even with the improvement of external and environmental factors, achieving customer satisfaction is highly dependent on the enjoyment of furniture production units from efficient management, skills and updated technologies.

\section{Appendix A. Supplementary material}

Supplementary data associated with this article can be found, in the online version, at http://dx.doi.org/10.14254/jems.2017.2-1.1

\section{Funding}

The authors received no direct funding for this research.

\section{Citation information}

Azizi, M., Dehghan, S., Ziaie, M., \& Mohebi, N. (2017). Identifying the customer satisfaction factors in furniture market. Economics, Management and Sustainability, 2(1), 6-18. doi:10.14254/jems.2017.2-1.1.

\section{References}

Applied Research \& Consulting LLC. (1999). Report to Ogilvy Public Relations Worldwide and the American Furniture Manufacturers Association.

Asgharpour. (1998). Multiple Criteria Decision Making. Tehran: Tehran University.

Beier, K. P. (1995). Virtual reality-advanced design and manufacturing. ESD Technology, 56(1), 2228.

Blery, E. K., \& Michalakopoulos, M. G. (2006). An e-CRM application in the telecommunications sector: A case study from Greece. EuroMed Journal of Business, 1(2), 5-14.

Bull, C. (2003). Strategic issues in customer relationship management (CRM) implementation. Business process management Journal, 9(5), 592-602.

Chen, S. J., \& Hwang, C. L. (1992). Fuzzy multiple attribute decision making methods. In Fuzzy Multiple Attribute Decision Making (pp. 289-486). Springer Berlin Heidelberg.

Dilip, S., Kinzil, K., \& Walker, M. (2007). Effects of Payment Mechanism on Spending Behavior: The Illusion of Liquidity. Retrieved from http://citeseerx.ist.psu.edu/viewdoc/summary?doi=?doi=10.1.1.24.3964

Drazen, P., \& Simester, D. (1998). Always Leave Home without It: Note. Massachusetts: Sloan School of Management.

Dröge, C., Vickery, S., \& Markland, R. E. (1994). Sources and outcomes of competitive advantage: an exploratory study in the furniture industry. Decision Sciences, 25(5-6), 669-689. 
Fornell, C. (1995). The quality of economic output: Empirical generalization about its distribution and relationship to market share. Marketing science, 14, 203-211.

Grigoroudis, E., \& Siskos, Y. (2002). Preference disaggregation for measuring and analysing customer satisfaction: The MUSA method. European Journal of Operational Research, 143(1), 148-170.

Grigoroudis, E., \& Siskos, Y. (2004). A survey of customer satisfaction barometers: Some results from the transportation-communications sector. European Journal of Operational Research, 152(2), 334-353.

Hayes, J., \& Dredge, F. (1998). Managing customer service. Gower Publishing, Ltd.

Hoseini, S. (2003). Pricing from jurisprudence \& economic point of view. Bohoose Eghtesadieh.

Jamal, A., \& Naser, K. (2002). Customer satisfaction and retail banking: an assessment of some of the key antecedents of customer satisfaction in retail banking. International Journal of Bank Marketing, 20(4), 146-160.

Jeong, Y., \& Lee, Y. (2010). A study on the customer satisfaction and customer loyalty of furniture purchaser in on-line shop. Asian Journal on Quality, 11(2), 146-156.

Jeong, Y., \& Lee, Y. (2010). A study on the customer satisfaction and customer loyalty of furniture purchaser in on-line shop. Asian Journal on Quality, 11(2), 146-156.

Kaplinsky, R., Memedovic, O., Morris, M., \& Readman, J. (2003). The Global Wood Furniture Value Chain: What Prospects for Upgrading by Developing Countries- The Case of South Africa. Vienna: UNIDO.

Kotler, P., Armstrong, G., Saunders, J., \& Wong, V. (2001). Principles of marketing. London: Prentice Hall.

Light, B. (2003). CRM packaged software: a study of organisational experiences. Business Process Management Journal, 9(5), 603-616.

Memariani, A., \& Adel Azar, M. (1995). AHP the new technic in collective multicriteria decision making. Management Knowledge, 22-32.

Mooteni, A. (2011). The Impact of organizational fame on the specific value of brand in service sector. Tehran.

Oh, H., Yoon, S. Y., \& Hawley, J. (2004). What virtual reality can offer to the furniture industry. Journal of Textile and Apparel, Technology and Management, 4(1), 1-17.

Pedrycz, W., \& Gomide, F. (1998). An introduction to fuzzy sets: analysis and design. Mit Press.

Phillips, M. D., \& Cho, B. R. (1998). An empirical approach to designing product specifications: a case study. Quality Engineering, 11(1), 91-100.

Quesada, H., \& Gazo, R. (2007). Methodology for determining key internal business processes based on critical success factors: A case study in furniture industry. Business Process Management Journal, 13(1), 5-20.

Ratnasingam, J. (1999). Furniture Costing in Perspective. Sys Data Network SdnBhd (Press Co.). Kuala Lumpur, 54-63.

Reed, J., \& Nicholusp, H. (1977). Method for measuring customer satisfaction. Chicago: eEnergy evaluation conference.

Saaty, T. (2000). Decision making for leaders. Pittsburg: RWA Publications.

Sangle, P. S., \& Awasthi, P. (2011). Consumer's expectations from mobile CRM services: a banking context. Business Process Management Journal, 17(6), 898-918.

Seeman, D., Elain, O., \& Margaret, O. (2006). Customer relationship management in higher education:Campus-Wide Information Systems. Emerald Group Publishing, 24-34.

Sun, H., \& Liu, M. (2009, December). Empirical Analysis on the Effect of Customer Relationship Management to the Customer Loyalty. In Wireless Networks and Information Systems, 2009. WNIS'09. International Conference on (pp. 147-149). IEEE.

Szymanowski, W., \& Olkowicz, M. (2010). Implementing new products the chance of furniture industry development. Forestry and Wood Technology, 354(72), 350-354. 
Tafazoli, F. (1977). The History of Economic Beliefs. Tehran: Iran National University.

Thompson, H. (1998). Marketing strategies: What do your customers really want?. Journal of Business strategy, 19(4), 16-21.

Valsamakis, V. P., \& Sprague, L. G. (2001). The role of customer relationships in the growth of smallto medium-sized manufacturers. International Journal of Operations \& Production Management, 21(4), 427-445.

Varva, T. (1997). Improving Your Measurement of Customer Satisfaction. ASQC Quality Press: Mil waukee.

Vickery, S. K., Dröge, C., \& Markland, R. E. (1997). Dimensions of manufacturing strength in the furniture industry. Journal of Operations Management, 15(4), 317-330.

Ziaie, M. (2009). "Fatigue" factor and it's position in design and engineering wooden constructs. Wood and Paper Industries.

Ziaie, M. (2010). Exploring the international procedures of furniture market 1998-2007. Wood and Paper Industries.

Ziaie, M., Mohamed, S., Ratnasinga, J., Noor, A., \& Saleh, R. (2012). Unsteadiness of the resourcebased competitive advantage in absence of competitive strategy: Lessons from the Malaysian wooden furniture industry. Journal of Applied Sciences, 12, 113-124.

Ziaie, M., Mohamed, S., Ratnasingam, J., Ghani, A., Noor, A., \& Saleh, R. (2011). Competitive strategy trends among the Malaysian wooden furniture industry: A strategic groups analysis. Journal of Applied sciences, 11(14), 2487-2499.

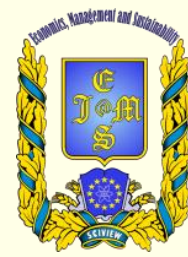

( 2016-2017, Economics, Management and Sustainability. All rights reserved.

This open access article is distributed under a Creative Commons Attribution (CC-BY) 4.0 license.

You are free to:

Share - copy and redistribute the material in any medium or format Adapt - remix, transform, and build upon the material for any purpose, even commercially.

The licensor cannot revoke these freedoms as long as you follow the license terms.

Under the following terms:

Attribution - You must give appropriate credit, provide a link to the license, and indicate if changes were made.

You may do so in any reasonable manner, but not in any way that suggests the licensor endorses you or your use.

No additional restrictions

You may not apply legal terms or technological measures that legally restrict others from doing anything the license permits.

Economics, Management and Sustainability (ISSN: 2520-6303) is published by Scientific Publishing House "CSR",

Poland, EU and Scientific Publishing House "SciView", Poland

Publishing with JEMS ensures:

- Immediate, universal access to your article on publication

- High visibility and discoverability via the JEMS website

Rapid publication

- Guaranteed legacy preservation of your article

Discounts and waivers for authors in developing regions

Submit your manuscript to a JEMS at http://jems.sciview.net or submit.jems@sciview.net

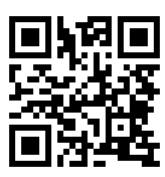

